\title{
8. IGNEOUS ROCKS FROM LEG 30 OF THE DEEP SEA DRILLING PROJECT
}

Douglas B. Stoeser, Center for Astrophysics, Smithsonian Astrophysical Observatory, Cambridge, Massachusetts

\section{INTRODUCTION}

Igneous rock units were encountered at four of the five sites drilled on Leg 30 of the Deep Sea Drilling Project. These units uncluded a diabase sill at Site 285 , a basalt underlain by a gabbro at 286 , two basalt flows at 287 , and a basalt flow at 289 . Site 285 is located approximately in the center of the South Fiji Basin, Site 286 is adjacent to a filled portion of the New Hebrides Trench, Site 287 is adjacent to a basement high in the Coral Sea Basin, and Sites 288 and 289 are located on the Ontong-Java Plateau north of the Solomon Islands (Figure 1).

Figure 2 presents generalized lithologic columns for the igneous rock units found at these sites. When a unit number is given, e.g., Site 286, Unit 4 basalt, this number conforms with the unit number assigned to it in the overall stratigraphic sequence of that hole as defined in the individual Site Reports in this volume. Unless otherwise stated, depths are given as measured from the sediment-igneous rock contact rather than the mudline.

\section{ANALYTICAL METHODS}

Analytical data reported here are from two sources-electron microprobe analysis, and whole rock wet chemical and spectroscopic analysis. The latter analyses were performed by the Analytical Laboratory of the U.S. Geological Survey. Major element analyses were obtained using a single solution procedure described in Geological Survey Professional Paper 575-B, 1967 , p. 187-191. The trace element data were obtained by a six-step semiquantitative spectroscopic procedure.

The microprobe analyses were performed at the Smithsonian Astrophysical Observatory, Cambridge, Massachusetts, using a three spectrometer MAC model 400 electron microprobe. Mineral analyses were largely performed with a focused beam of approximately $2 \mu \mathrm{m}$ diameter. In general, three-element analyses were performed on pyroxenes and plagioclases and their compositions calculated from stoichiometry. Whole rock analyses were performed by defocused beam, with a beam diameter of $50 \mu \mathrm{m}$. When data are presented in tables and figures, particular details of the analyses used are given in the captions. Sample numbers and locations are given in the form: site-core-section, centimeters from the top of the section (e.g., 285-7-6, 143), although the site number is usually deleted when obvious. A "CC" designation in place of the section number indicates that the sample is from the core catcher located just below the core tube.

\section{SITE 285}

Basaltic rock was encountered at 564 meters below the mudline in the second hole drilled at this site (285A).

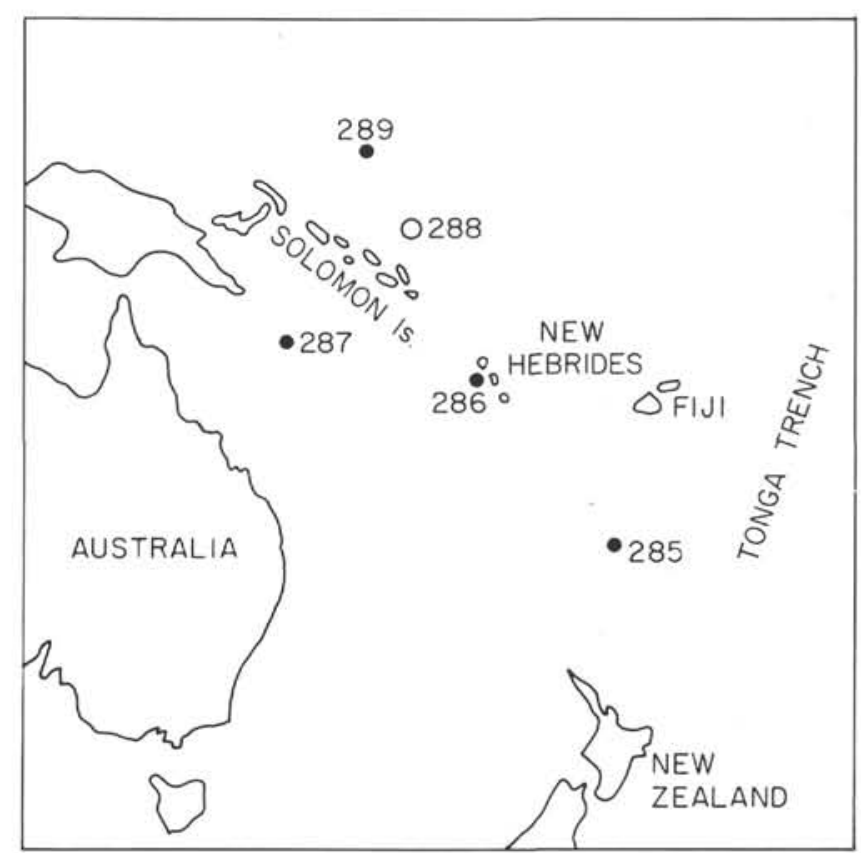

Figure 1. Leg 30 drill sites.

An interval of 19.7 meters of basalt, grading downwards to diabase, was cored. The unit is interpreted as a sill because of its dominantly diabasic texture and because the middle Miocene sediment immediately above appears baked and contains highly altered glasses which have been devitrified or extensively altered to ferric oxides. Drilling was terminated before the bottom of the sill was reached. The sill can be divided into three zones (in descending order): the chill zone, the amygdaloidal zone, and the diabase zone.

\section{Chill Zone (0.0-0.7 m)}

The top of the uppermost piece of basalt appears to be a fracture surface to which a portion of a ferriceladonite(?)-calcite vein adheres; therefore, the actual basalt sediment contact was not preserved. The rock of the chill zone is fine grained, with an average grain size of approximately $100 \mu \mathrm{m}$ or less (Figure $3 \mathrm{~A}$ ). Within a few centimeters of the top, the rock has an intersertal texture with laths of plagioclase which occasionally show the hollow habit, crystallites of quench pyroxene and magnetite, and a very fine-grained groundmass of hydrous alteration minerals (largely chlorite and smectite?). Toward the bottom of the chill zone, the rock still has an intersertal texture, but the pyroxene is moderately well developed. Augite and plagioclase phenocrysts up to approximately $1 \mathrm{~mm}$ in length are rare but present throughout the chill zone and 


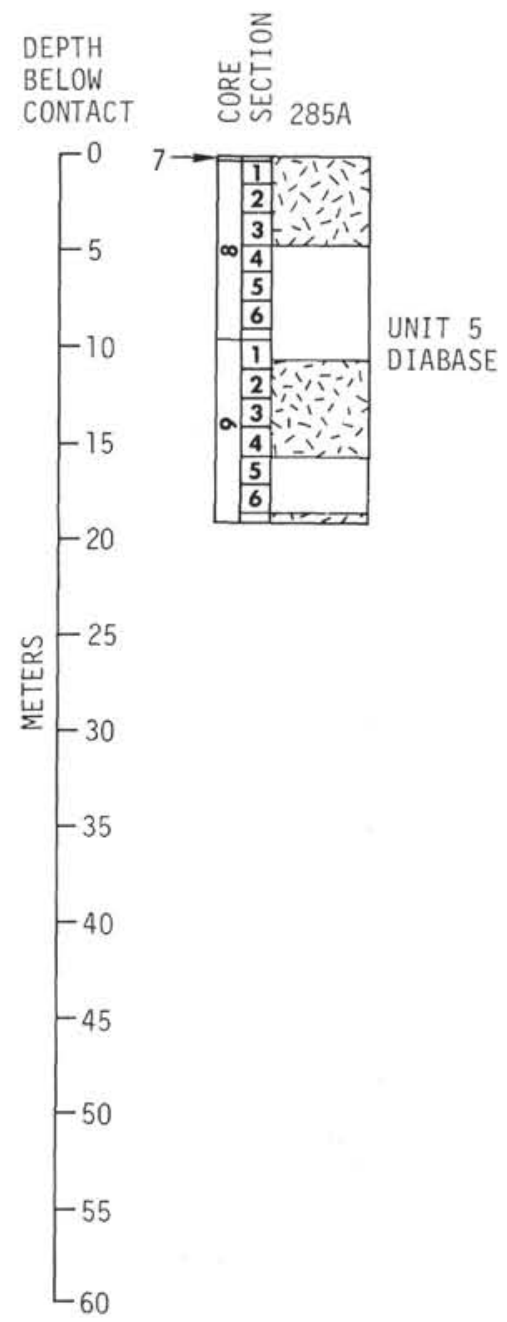

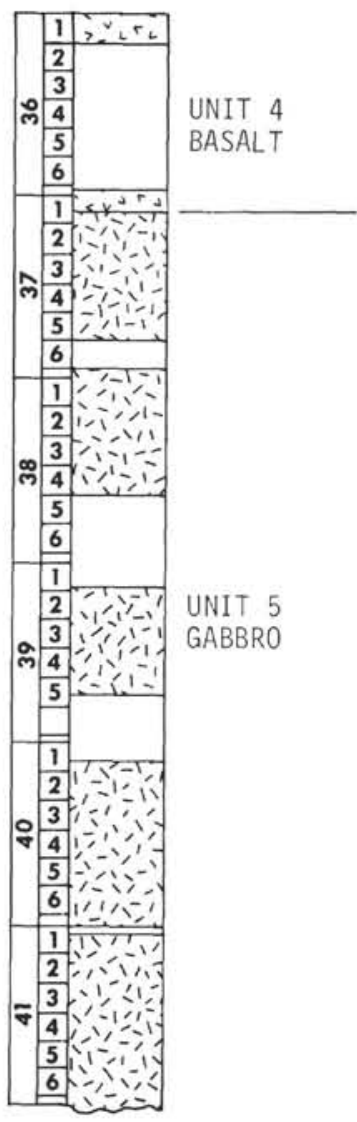

287

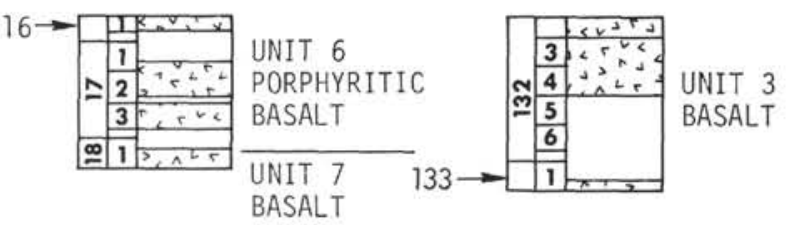

KEY :

$\because \div, r_{L}$ EXTRUSIVE BASALTS

E:1: INTRUSIVE ROCKS

Figure 2. Generalized lithologic columns for igneous rocks of Leg 30. Blank portions of the lithic columns indicate that those portions of the core were empty. The small unnumbered section at the base of each core interval is the core catcher section.

the upper part of the sill. Hydrous alteration of the plagioclase and pyroxene is extensive throughout the chill zone, and small veins of brilliant, emerald green vermicular ferriceladonite (?) and calcite are common (Figure 3D).

\section{Amygdaloidal Zone (0.7-2.1 m)}

This zone is defined by abundant amygdules that average about $3 \mathrm{~mm}$ in diameter, but may range up to 8 $\mathrm{mm}$. Their maximum development occurs at 1.2 meters, where they comprise approximately $15 \%$ to $20 \%$ of the rock. The amygdules are filled mainly by a soft, pale green material (antigorite?), and by lesser amounts of ferriceladonite (?), calcite, chlorite, and traces of pyrite. The bulk of the rock in this zone has a well-developed diabasic texture with an average grain size of approximately $0.3 \mathrm{~mm}$. The plagioclase has a maximum length of $0.8 \mathrm{~mm}$, while the pyroxene and opaque minerals (magnetite plus ilmenite?) have maximum diameters of approximately $0.4 \mathrm{~mm}$.

\section{Diabase Zone (2.1-19.7 m)}

The bulk of the diabase zone has a uniform diabasic (subophitic) texture and an average grain size of 0.3-0.4 $\mathrm{mm}$. The maximum length of the plagioclase laths is 0.8 $\mathrm{mm}$, and the maximum diameter of the pyroxene is approximately $0.3 \mathrm{~mm}$. Seven to nine percent skeletal titanomagnetite, up to $0.4 \mathrm{~mm}$ in diameter and without exsolution lamellae, is present. Radiating subvariolitic clusters of plagioclase and pyroxene, which are finer grained in the center than at the margins, occur throughout the diabase zone (Figure 3C). Microprobe analyses indicate that the most magnesian pyroxenes and calcic plagioclases detected in the samples are found in these finer grained cores, and these therefore represent nucleation centers in the parental magma.

In thin sections taken from Core 9, Section 2 to Core 9, Section 4 (Figure 2), a clear, honey-brown to yellow mineral was found. In transmitted light it is seen as disseminated, homogeneous, usually rounded grains up to $0.2 \mathrm{~mm}$ in diameter that have sharp contacts against fresh plagioclase and pyroxene, or as spherical inclusions in plagioclase, thus indicating an early paragenesis. The mineral takes a poor polish and appears to be very soft. In crossed polarizers, the apparently homogeneous grains of this mineral are seen to be composite rather than single crystals (Figure $3 \mathrm{E}, \mathrm{F}$ ). In one case, this mineral has the outline typical of olivine (Figure 3E). Table 1 (analysis 1) presents the average of four microprobe analyses of this material. This average 


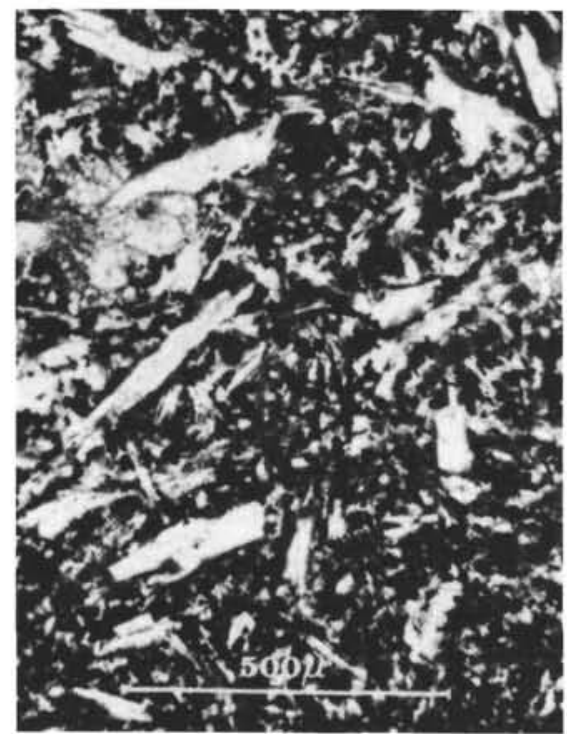

A

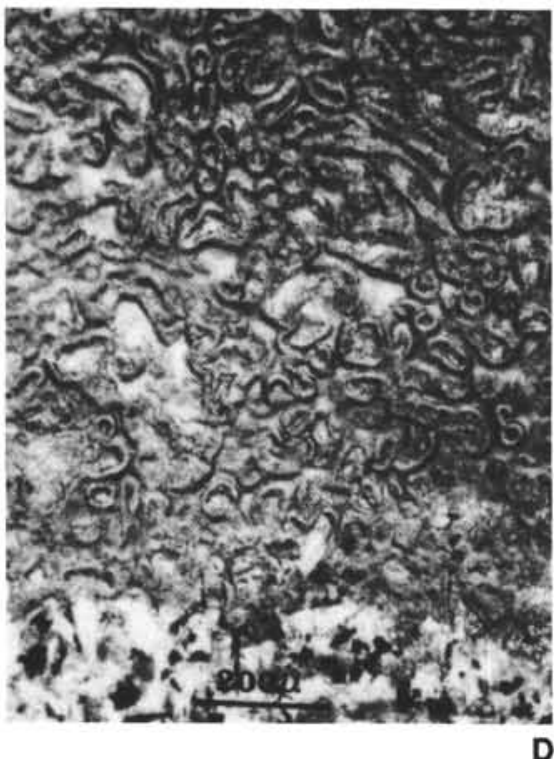

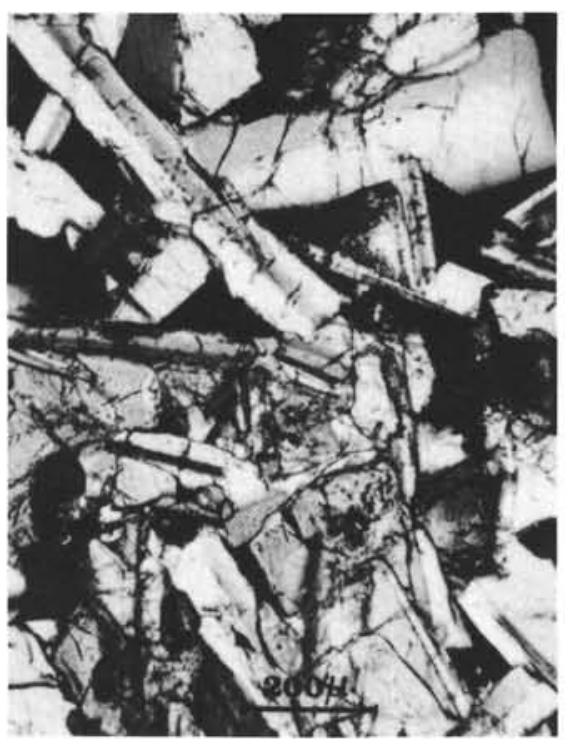

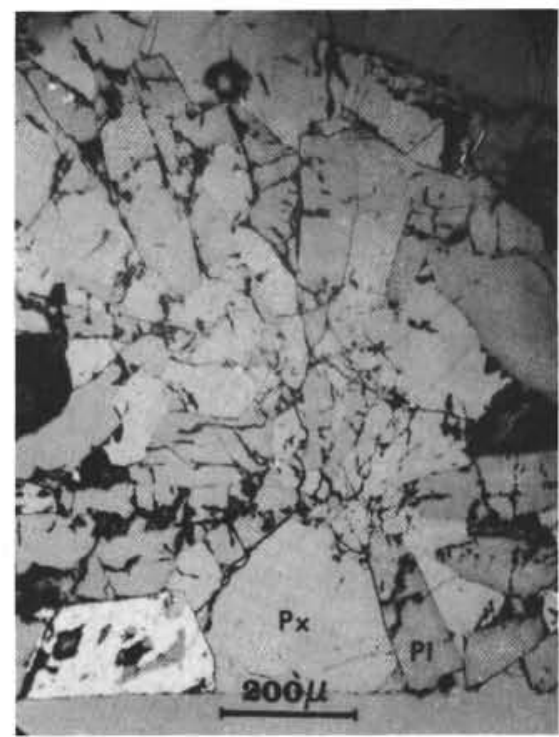

B
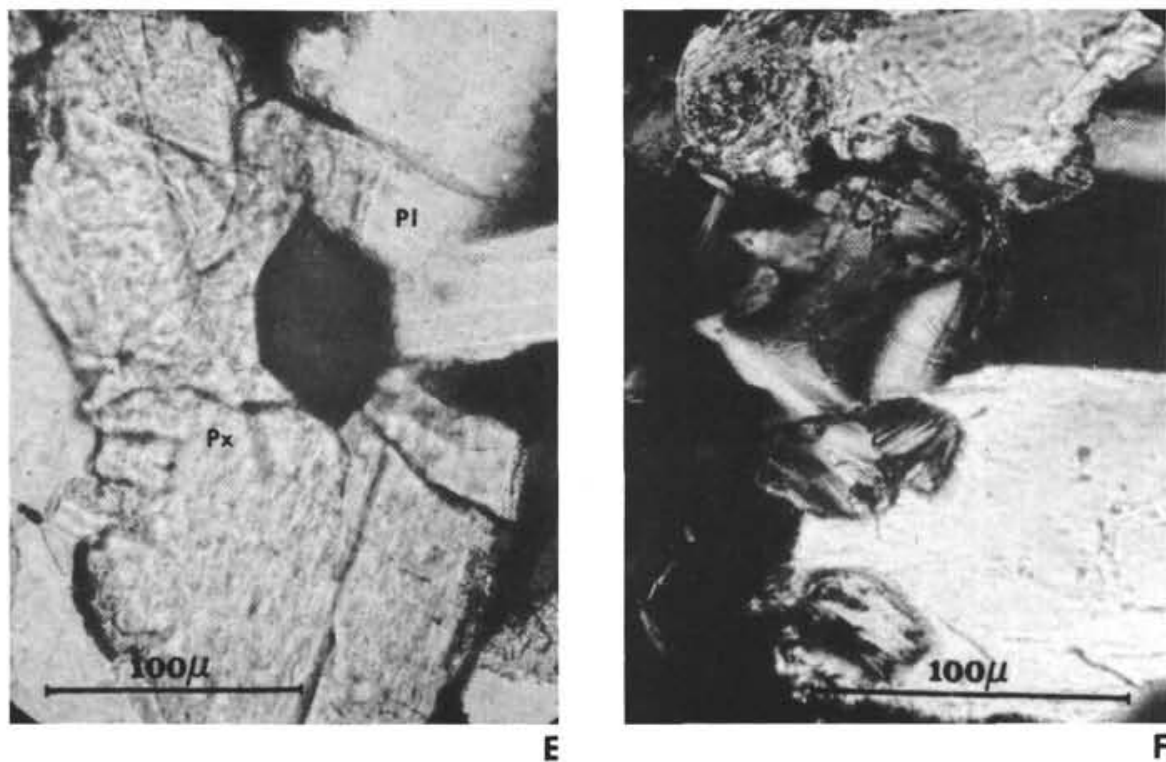

Figure 3. Photomicrographs of Site 285 samples. (A) 285-7-6, $135 \mathrm{~cm}$, diabase chill zone rock (uncrossed polarizers). (B) $285-9-4,143 \mathrm{~cm}$, typical fresh diabase from the deepest part of the sill sampled (crossed-polarizers). (C) 285-8-3, 80 cm, reflected light photograph of subvariolitic cluster of plagioclase (pl) and pyroxene (px). The most magnesian pyroxene and the most calcite plagioclase are found at the center of the cluster. The bright mineral at the lower left is titanomagnetite, and the dark areas are holes. (D) 285-7-6, $145 \mathrm{~cm}$, vermicular ferriceladonite plus calcite vein. The host basalt can be seen at the bottom of the photograph (uncrossed polarizers). (E) 285-9-4, $143 \mathrm{~cm}$, chlorophaeite pseudomorph after olivine. Note the sharp contact of the chlorophaeite (dark) against the enclosing pyroxene (px) and plagioclase (pl) (uncrossed polarizers). (F) 285-9-4, $143 \mathrm{~cm}$, three clusters of chlorophaeite as seen with crossed polarizers (center and bottom). In plain light they appear to be homogeneous single crystals.

analysis is very similar to those of chlorophaeite and iddingsite, both of which are hydrous alteration products of olivine (Table 1) (Deer et al., 1962). If this mineral is indeed one of these materials, the low total of its analysis can be attributed to undetected water of crystallization, although it is also partly attributable to a small amount of porosity. It is concluded that this mineral is an alteration product of olivine, although it is strange that the replacement process was so complete that no trace of olivine is left, while the neighboring pyroxene and plagioclase are apparently unaffected.

Another unusual feature of the diabase zone is the occurrence of two small gabbroic zones at 9-2, 93-104 cm and $9-3,26-33 \mathrm{~cm}$. Only the latter was examined in thin section. It consists of approximately $40 \%$ coarse plagioclase laths with maximum lengths of $6 \mathrm{~mm}, 35 \%$ pyroxene with maximum diameters of $2-1 / 2 \mathrm{~mm}$, sparse chlorophaeite pseudomorphs after olivine, sparse 
TABLE 1

Site 285A Electron Microprobe Mafic Mineral Analyses

\begin{tabular}{|c|c|c|c|c|c|c|c|}
\hline & \multirow{2}{*}{$\begin{array}{c}\text { (1) } \\
\text { Olivine } \\
\text { Pseudomorphs } \\
9-4,143 \mathrm{~cm}\end{array}$} & \multicolumn{2}{|c|}{$\begin{array}{c}\text { (2) } \\
\text { Chlorophaeite }^{\mathrm{a}}\end{array}$} & \multirow{2}{*}{$\begin{array}{c}\text { (3) } \\
\text { Diabase } \\
\text { Augite } \\
9-4,143 \mathrm{~cm}\end{array}$} & \multirow{2}{*}{$\begin{array}{c}\text { (4) } \\
\text { Gabbro } \\
\text { Augite } \\
9-3,29 \mathrm{~cm}\end{array}$} & \multirow{2}{*}{$\begin{array}{c}(5) \\
\text { Gabbro } \\
\text { Augite } \\
9-3,29 \mathrm{~cm}\end{array}$} & \multirow{2}{*}{$\begin{array}{c}\text { (6) } \\
\text { Mesostasis } \\
\text { Augite } \\
9-3,29 \mathrm{~cm}\end{array}$} \\
\hline & & Average & Range & & & & \\
\hline $\mathrm{SiO}_{2}$ & 48.5 & 45.11 & $43.42-48.17$ & 53.1 & 51.2 & 49.4 & 49.0 \\
\hline $\mathrm{TiO}_{2}$ & 0.14 & 0.29 & $0.00-0.82$ & 0.59 & 1.12 & 1.21 & 1.9 \\
\hline $\mathrm{Cr}_{2} \mathrm{O}_{3}$ & n.d. ${ }^{b}$ & - & - & 0.03 & 0.03 & 0.01 & n.d. \\
\hline $\mathrm{Al}_{2} \mathrm{O}_{3}$ & 44 & 391 & $1.37-7.12$ & 1.62 & 2.86 & 1.14 & 2.51 \\
\hline $\mathrm{Fe}_{2} \mathrm{O}_{3}$ & - & 22.13 & $12.37-30.02$ & - & - & - & - \\
\hline $\mathrm{FeO}$ & 23.2 & 6.66 & $2.36-12.10$ & 9.2 & 10.6 & 21.6 & 20.0 \\
\hline $\mathrm{MnO}$ & 05 & 0.47 & $0.35-0.62$ & 0.2 & - & - & - \\
\hline $\mathrm{MgO}$ & 10.4 & 8.16 & $6.26-11.73$ & 16.4 & 16.9 & 9.4 & 8.8 \\
\hline $\mathrm{CaO}$ & 2.1 & 3.13 & $1.97-4.02$ & 18.8 & 16.6 & 15.7 & 16.7 \\
\hline $\mathrm{Na}_{2} \mathrm{O}$ & 0.24 & 0.55 & $0.00-2.21$ & 0.35 & 0.22 & 0.22 & 0.29 \\
\hline $\mathrm{K}_{2} \mathrm{O}$ & 0.49 & 0.14 & tr. -0.47 & n.d. & n.d. & n.d. & n.d. \\
\hline $\mathrm{H}_{2} \mathrm{O}+$ & - & 8.39 & $6.83-10.97$ & - & - & - & - \\
\hline Total & 89.97 & 98.94 & & 100.29 & 99.53 & 98.68 & 99.23 \\
\hline En & - & - & & 46.8 & 48.6 & 28.8 & 27.6 \\
\hline Wo & - & - & & 38.5 & 34.3 & 34.3 & 37.5 \\
\hline Fs & - & - & & 14.7 & 17.1 & 36.9 & 34.9 \\
\hline
\end{tabular}

${ }^{\text {a }}$ Taken from Deer et al., 1962, for comparison with analysis 1 .

$\mathrm{b}_{\text {n.d. }}=$ not detected.

titanomagnetite, and approximately $20 \%$ fine-grained mesostasis. The plagioclase has a marked normal zoning with some sharp internal extinction boundaries, and in a few cases the cores exhibit sector(?) zoning. The pyroxenes have marked fan-like sector (?) zoning. The zoning of the plagioclase and pyroxene is only strongly developed where the crystals are adjacent to the mesostasis. The crystals tend to be euhedral adjacent to the mesostasis and clearly have grown into it. The mesostasis has a variolitic texture and contains euhedral to subhedral titanomagnetite and pyroxene.

\section{Mineral and Whole Rock Chemistry}

The occurrence of probable olivine pseudomorphs towards the bottom of the sill suggests the possibility of crystal settling. The possibility that the sill is fractionated does not appear to be supported by the mineral compositional data, however. The maximum content of enstatite component of pyroxenes from throughout the sill are essentially the same with all of the earliest pyroxene falling into the narrow compositional range $\mathrm{En}_{52}$ ${ }_{49} \mathrm{WO}_{37-41} \mathrm{FS}_{9-14}$ (Figure 4A). The plagioclases of the diabase show only a moderate amount of zoning and are essentially the same throughout the sill with average compositions in the range $\mathrm{An}_{59-52}$ (Table 2). The content of orthoclase component in the plagioclase is less than 0.2 for all but the most sodic samples and never exceeds 0.5 .

The plagioclase and pyroxene of the gabbro zone at 9$3,26-33 \mathrm{~cm}$ have more extended compositional ranges than those of the diabase. The coarsest plagioclases show a smooth compositional trend of $\mathrm{An}_{60} \mathrm{Or} 0.1$ to $A n_{30}$ Oro.6. The pyroxenes are all augites which show a moderate amount of zoning with no clearcut compositional trend (Figure 4A). The most magnesian pyroxene analyzed from the gabbro was $\mathrm{En}_{49} \mathrm{~W}_{0_{34}} \mathrm{Fs}_{17}$. The titanomagnetites were titanium rich with about $22 \%$ $\mathrm{TiO}_{2}, 2 \% \mathrm{Al}_{2} \mathrm{O}_{3}$, and $1.2 \% \mathrm{MgO}$ (2 analyses), which compared closely with a small euhedral titanomagnetite from the mesostasis which contained $24 \% \mathrm{TiO}_{2}, 1 \%$ $\mathrm{Al}_{2} \mathrm{O}_{3}$, and $0.8 \% \mathrm{MgO}$. No exsolution was visible in the titanomagnetites when viewed in reflected light.

The minerals of the gabbro mesostasis indicate that it was a highly fractionated liquid. The plagioclases have compositions of $\mathrm{An}_{25-18} \mathrm{Or}_{0.8-1.1}$ ( 3 analyses) and the pyroxenes were about $\mathrm{En}_{26} \mathrm{WO}_{37} \mathrm{Fs}_{37}$ (Figure 4A, Table 1). Diabase Sample 9-4, $143 \mathrm{~cm}$ also contains a small amount of similar mesostasis and the plagioclases had compositions of $\mathrm{An}_{6-8} \mathrm{Or}_{2}$ ( 2 analyses). Unfortunately, the mesostasis areas did not take a polish, and microprobe analysis of the whole mesostasis was not possible. The decrease in silica content of the gabbro pyroxenes as iron content increases (Table 1), combined with the lack of visible silica in the mesostasis, suggests the possibility that the mesostasis is alkaline rather than oversaturated or granitic. The earliest plagioclase and pyroxene of the gabbro zone are comparable in composition to those of the normal diabase, and therefore, it would appear that the composition of the parental liquid was similar, but in the case of the gabbroic pockets more extensive local fractionation occurred.

Only one analysis of rock from the sill is available, and the sample used was taken from the chill zone, 17 $\mathrm{cm}$ below the top of the unit (Tables 3,4). Assuming that the analysis is representative of the parental magma, then it was a titanium-rich quartz normative tholeiite 

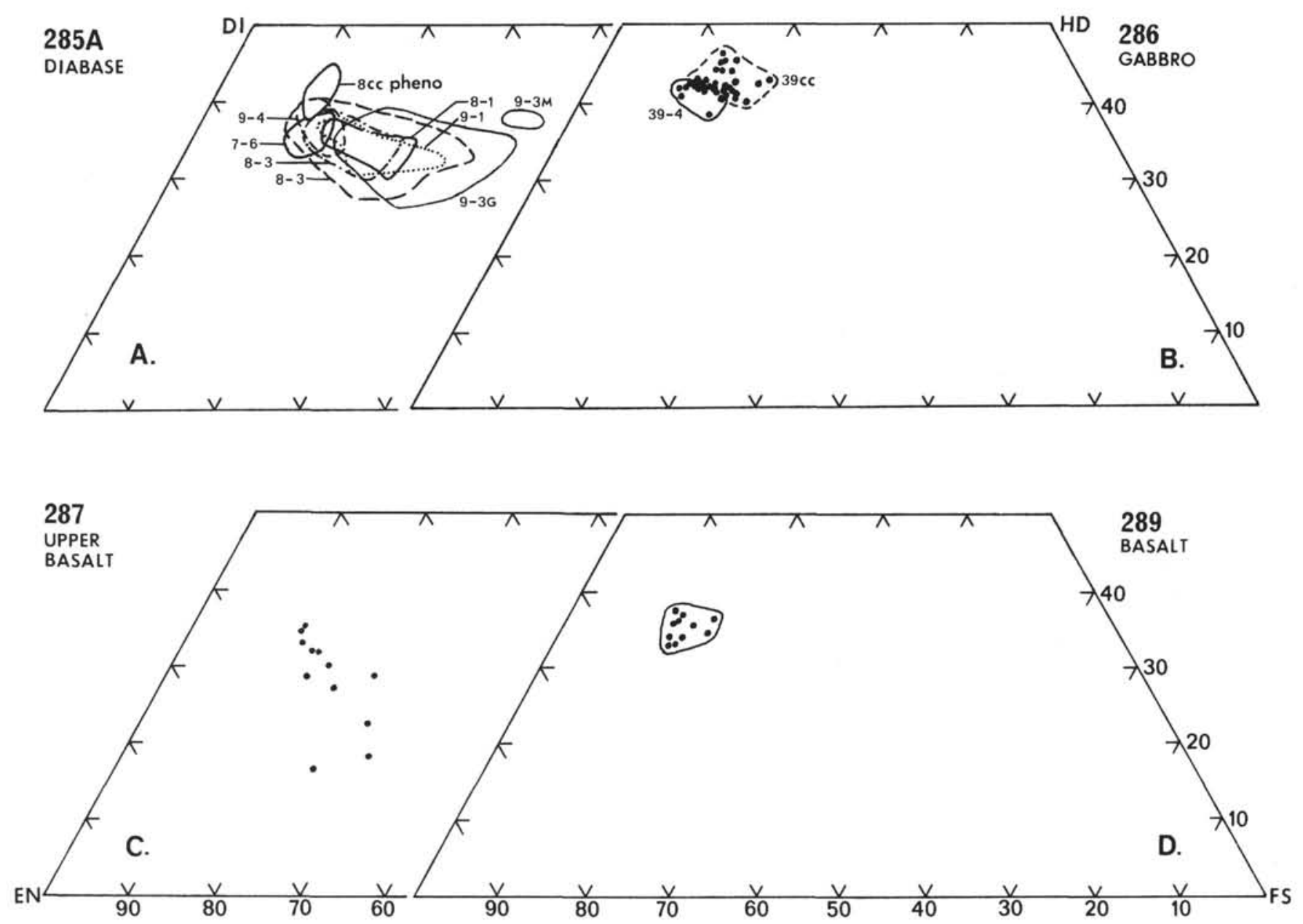

Figure 4. Pyroxene quadralaterals. The data represented on the diagrams were obtained by three-element (Mg, Ca, Fe) microprobe surveys except 285-9, $3 G$ and 285-9, $3 M$ which were complete analyses. (A) Site 285. Because of the abundance of data points, only the fields for each core sample are shown. In most cases, the bulk of data points for each sample lie in the left portion of the field. The fields labeled 9-3G and 9-3M are from the gabbro zone at 9-3, $29 \mathrm{~cm} / G$-large pyroxenes, M-mesostasis pyroxenes). (B) Site 286, Unit 5 gabbro. Because of the intense alteration to most samples, pyroxenes from only two samples were analyzed, 39-4, 40 and 39, CC. (C) Site 287, Unit 6 basalt. All data points are from Sample 17, CC.

(d) Site 289. All data points are from Sample 132-2, $90 \mathrm{~cm}$.

TABLE 2

Anorthite Content of Plagioclase from Hole 285A Diabase

\begin{tabular}{cccr}
\hline $\begin{array}{c}\text { Sample } \\
\text { (Interval in cm) }\end{array}$ & Ave. An $^{\mathrm{a}}$ & Range & $n^{\mathrm{b}}$ \\
\hline $7-6,145$ & 55 & $62-47$ & 10 \\
$8-1,106$ & 59 & $64-53$ & 9 \\
$8-3,80$ & 52 & $59-36$ & 10 \\
$9-1,98$ & 52 & $62-35$ & 12 \\
$9-4,143$ & 56 & $64-44$ & 12 \\
\hline
\end{tabular}

${ }^{\mathrm{a}}$ Anorthite content.

$\mathrm{b}_{n}=$ number of analyses per sample.

(Figure 5). When plotted on Kuno's (1968) aluminatotal alkali diagram, it plots at the junction between his three major basalt types, tholeiite-high alumina basalt- olivine alkali basalt. Because of the extensive alteration of many deep-sea samples, alteration-resistant minor and trace elements are being used as indicators of rock type (Bass et al., 1973; Rhodes, 1973). In Figures 6 and 7 , it may be seen that by this approach this sample fails to fall into a single category, but resembles both midocean ridge and ocean island tholeiites. In light of its oversaturated nature and the sparse plagioclase and augite phenocrysts of the chill zone, the possible occurrence of olivine in much of the sill appears contradictory. The possibility that magma of this composition would crystallize such that an undersaturated mesostasis would be produced also seems unlikely. The analyzed sample, therefore, may not be representative of the composition of the parental magma of the sill, possibly because of alteration, although the sample does not appear to be extensively altered. 
TABLE 3

Major Element Whole-Rock Analyses

\begin{tabular}{|c|c|c|c|c|c|c|c|c|c|c|}
\hline & $\begin{array}{c}(1) \\
285 \mathrm{~A}-7-6, \\
147 \mathrm{~cm} \\
\text { Diabase } \\
\text { Chill } \\
\text { Zone }\end{array}$ & $\begin{array}{c}(2) \\
286-36-1, \\
125 \mathrm{~cm} \\
\text { Sidero- } \\
\text { melane } \\
\text { Vein }\end{array}$ & $\begin{array}{c}(3) \\
286-36-1, \\
125 \mathrm{~cm} \\
\text { Sidero- } \\
\text { melane } \\
\text { Aystallites }\end{array}$ & $\begin{array}{c}(4) \\
286-36-1 \text {, } \\
132 \mathrm{~cm} \\
\text { Basalt }\end{array}$ & $\begin{array}{c}(5) \\
286-37-1 \text {, } \\
72 \mathrm{~cm} \\
\text { Gabbro } \\
\text { Chill } \\
\text { Zone }\end{array}$ & $\begin{array}{c}(6) \\
286-37-1, \\
72 \mathrm{~cm} \\
\text { Ground- } \\
\text { mass }\end{array}$ & $\begin{array}{c}\text { (7) } \\
287-17, \mathrm{CC} \\
\text { Porphyritic } \\
\text { Basalt }\end{array}$ & $\begin{array}{c}(8) \\
287-18-1, \\
147 \mathrm{~cm} \\
\text { Basalt }\end{array}$ & $\begin{array}{c}(9) \\
289-132-3 \text {, } \\
50 \mathrm{~cm} \\
\text { Basalt }\end{array}$ & $\begin{array}{c}(10) \\
289-132-4, \\
27 \mathrm{~cm} \\
\text { Basalt }\end{array}$ \\
\hline $\mathrm{SiO}_{2}$ & 52.1 & 49.8 & 50.2 & 49.2 & 51.2 & 60.0 & 49.4 & 48.8 & 48.3 & 49.4 \\
\hline $\mathrm{TiO}_{2}$ & 2.5 & 1.5 & 1.3 & 1.5 & 1.4 & 1.1 & 0.59 & 1.2 & 1.5 & 1.6 \\
\hline $\mathrm{Cr}_{2} \mathrm{O}_{3}$ & - & 0.07 & 0.19 & - & - & 0.04 & - & - & - & - \\
\hline $\mathrm{Al}_{2} \mathrm{O}_{3}$ & 15.8 & 16.4 & 14.7 & 16.6 & 14.7 & 18.8 & 16.2 & 18.7 & 14.7 & 14.9 \\
\hline $\mathrm{Fe}_{2} \mathrm{O}_{3}$ & 4.3 & - & - & 3.4 & 3.2 & - & 1.7 & 4.0 & 4.3 & 4.1 \\
\hline $\mathrm{FeO}$ & 4.5 & 8.7 & 8.8 & 6.2 & 4.8 & 2.0 & 6.4 & 4.0 & 8.2 & 7.5 \\
\hline $\mathrm{MnO}$ & 0.54 & 0.20 & 0.19 & 0.12 & 0.27 & 0.19 & 0.11 & 0.03 & 0.19 & 0.14 \\
\hline $\mathrm{MgO}$ & 6.8 & 8.2 & 8.7 & 7.6 & 10.8 & 0.48 & 10.8 & 7.2 & 6.9 & 6.6 \\
\hline $\mathrm{CaO}$ & 8.3 & 10.9 & 11.0 & 9.9 & 3.1 & 1.3 & 12.6 & 9.1 & 11.6 & 10.6 \\
\hline $\mathrm{Na}_{2} \mathrm{O}$ & 3.5 & 3.4 & 3.3 & 2.4 & 1.5 & 0.73 & 1.5 & 2.7 & 2.2 & 2.3 \\
\hline $\mathrm{K}_{2} \mathrm{O}$ & 0.62 & 0.10 & 0.12 & 0.87 & 5.7 & 13.7 & 0.20 & 0.34 & 0.45 & 0.34 \\
\hline $\mathrm{P}_{2} \mathrm{O}_{5}$ & 0.29 & 0.17 & 0.08 & 0.09 & 0.12 & 0.12 & 0.03 & 0.06 & 0.12 & 0.14 \\
\hline $\mathrm{H}_{2} \mathrm{O}+$ & 0.74 & - & - & 1.9 & 2.7 & - & 0.52 & 3.8 & 1.5 & 2.2 \\
\hline $\mathrm{CO}_{2}$ & 0.03 & - & - & 0.15 & 0.48 & - & 0.08 & 0.08 & 0.07 & 0.02 \\
\hline Total & 100.02 & 99.44 & 98.58 & 99.93 & 99.97 & 98.46 & 100.03 & 100.01 & 100.03 & 99.84 \\
\hline FO & 0.0 & 9.5 & 7.7 & 2.8 & 12.8 & 0.6 & 0.0 & 1.1 & 2.4 & 0.0 \\
\hline FA & 0.0 & 3.4 & 2.5 & 1.2 & 3.0 & 0.5 & 0.0 & 0.4 & 1.5 & 0.0 \\
\hline EN & 19.0 & 9.9 & 13.8 & 17.7 & 13.4 & 0.5 & 27.0 & 19.1 & 16.4 & 18.9 \\
\hline wo & 5.5 & 9.5 & 11.7 & 6.8 & 0.0 & 0.0 & 9.2 & 2.8 & 11.5 & 9.3 \\
\hline FS & 6.9 & 35 & 4.4 & 7.2 & 3.2 & 0.4 & 9.5 & 6.7 & 10.2 & 11.0 \\
\hline OR & 3.7 & 0.6 & 0.7 & 5.3 & 34.3 & 82.5 & 1.2 & 2.1 & 2.7 & 2.1 \\
\hline $\mathrm{AB}$ & 31.7 & 304 & 29.7 & 22.1 & 13.7 & 6.6 & 5.0 & 25.1 & 20.4 & 21.5 \\
\hline AN & 25.8 & 29.1 & 25.0 & 32.7 & 14.9 & 5.8 & 41.0 & 39.2 & 29.8 & 30.5 \\
\hline COR & 0.0 & 0.0 & 0.0 & 0.0 & 0.8 & 0.8 & 0.0 & 0.0 & 0.0 & 0.0 \\
\hline QTZ & 1.5 & 0.0 & 0.0 & 0.0 & 0.0 & 0.0 & 2.8 & 0.0 & 0.0 & 1.6 \\
\hline $\mathrm{NE}$ & 0.0 & 0.0 & 0.0 & 0.0 & 0.0 & 0.0 & 0.0 & 0.0 & 0.0 & 0.0 \\
\hline AP & 0.6 & 0.4 & 0.2 & 0.2 & 0.3 & 0.3 & 0.1 & 0.1 & 0.3 & 0.3 \\
\hline IL & 3.5 & 2.1 & 2.5 & 2.1 & 2.0 & 1.6 & 1.1 & 1.7 & 2.2 & 2.3 \\
\hline MT & 1.8 & 1.8 & 1.9 & 2.0 & 1.7 & 0.4 & 2.5 & 1.7 & 2.6 & 2.5 \\
\hline
\end{tabular}

Note: 1, 4, 5, 7-10: USGS analyses (see Analytical Methods section of this paper); 2: average of $1250 \mu \mathrm{m}$ diameter defocused beam microprobe analyses (DBAs); 3: one $50 \mu \mathrm{m}$ diameter DBA; 6: average of $1750 \mu \mathrm{m}$ diameter DBAs. All norms were calculated with an atomic ratio of Fe $\mathrm{e}^{+3}$ $\mathrm{Fe}^{+2}=0.2$, except analysis 7 which was calculated directly from the analysis. 


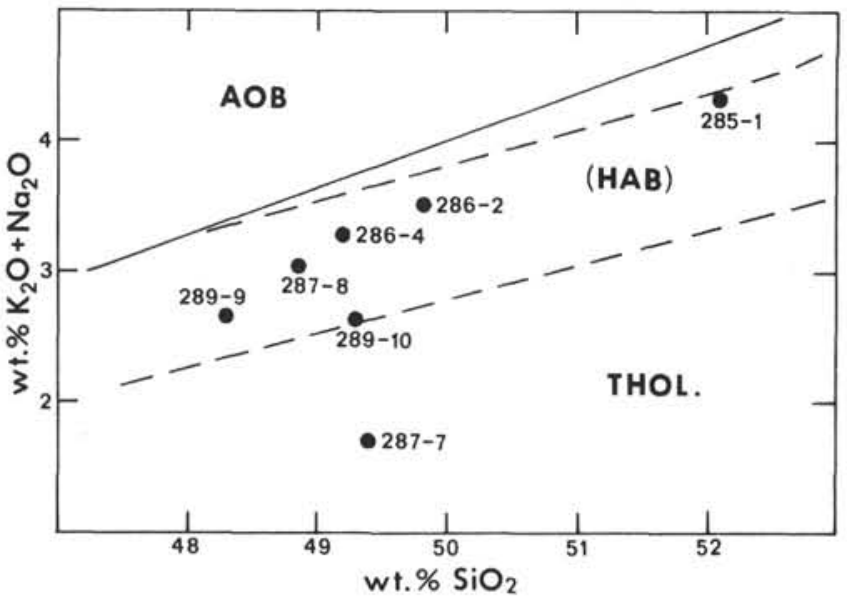

Figure 5. Silica versus total alkalis diagram for Leg 30 igneous rocks. The first number by each data point is the site number and the second number is the analysis number given in Table 3. The solid line is that of MacDonald and Katsura (1964) which they used to divide Hawaiian basalts into two groups, alkali basalts (AOB) and tholeiites (THOL.). The dashed lines which subdivide the diagram into three fields are those used by Kuno (1968) to divide Japanese basalts into three groups, alkali olivine basalt $(A O B)$, high alumina basalt (HAB) and tholeiite (THOL.).

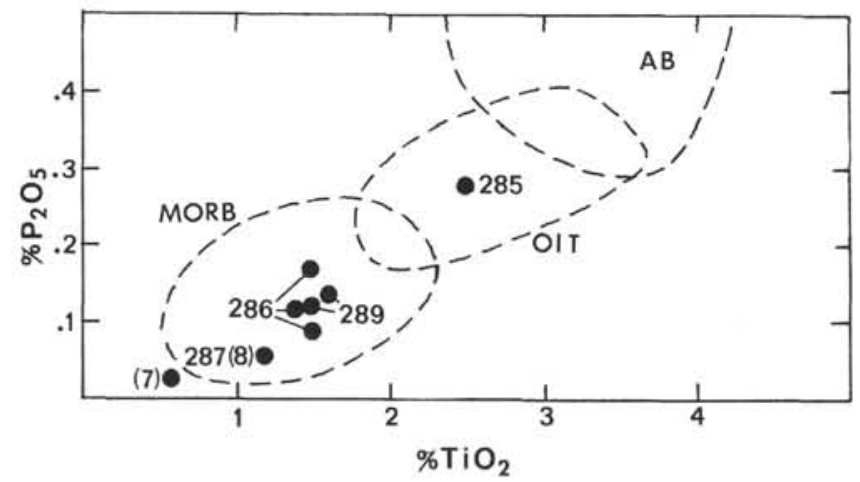

Figure 6. $\mathrm{TiO}_{2}$ versus $\mathrm{P}_{2} \mathrm{O}_{5}$ diagram for Leg 30 igneous rocks. Data used are taken from Table 3, and numbers in parentheses are analysis numbers from that table. Field boundries are taken from Bass et al., 1973 (MORB= mid-ocean ridge basalts, OIT=ocean island tholeites, $A B=$ alkali basalt $)$.

\section{SITE 286}

The igneous rocks encountered in the Site 286 cores consist of clasts of fresh volcanic rocks in a 91-meter thick, upper Eocene andesitic conglomerate unit and basaltic rocks at the base of the section. The basaltic rocks are divided into two units, an upper 10-meterthick basalt and a lower gabbro, of which only 47 meters were cored (Figure 2).

\section{Andesitic Conglomerate (330-441 m below mudline)}

This sedimentary unit is composed mainly of lithic clasts of volcanic rocks of great variety, although sedimentary rock clasts and fossil debris are also rarely present. Only the detailed petrography of the volcanic clasts will be described here; for more information on this unit, refer to the earlier chapter devoted to this site. The petrographic description which follows was written by Norman S. MacLeod of the U.S. Geological Survey, Menlo Park, California. Mineral composition data were obtained optically.

The cored rock consists of poorly sorted, angular to subangular clasts that are set in a fine gray-colored clastic matrix. The clasts are mainly $1 \mathrm{~mm}$ to $1 \mathrm{~cm}$ long, but one large clast is approximately $2.5 \mathrm{~cm}$ long. The clasts consist almost entirely of volcanic rocks and their disaggregation or alteration products. Texture and structure of the clasts are variable, due in part to the range in crystallinity from essentially holohyaline to holocrystalline. Many of the glassier clasts are slightly vesicular to highly vesicular (pumiceous). Some highly vesicular clasts contain round vesicles as much as 0.5 $\mathrm{mm}$ across; others contain stretched bubbles as long as the clasts, but bubbles in most clasts are flattened or stretched to elongate ellipsoidal shapes. Most clasts are porphyritic, microporphyritic, or vitrophyric, and they commonly have intersertal, hyalophitic, and/or pilotaxic textures. The crystalline clast types are hypersthene augite andesite and augite andesite, less abundant hornblende andesite, and basaltic andesite. The similar phenocryst content of many glassy and crystalline clasts suggests that they have a similar composition.

The largest clast $(2.5 \mathrm{~cm})$ is a porphyritic hypersthene augite andesite that shows weakly developed flow banding. It consists of phenocrysts of plagioclase (16\%), hypersthene $(5 \%)$, and augite $(1 \%)$, set in a matrix of glass $(45 \%)$, plagioclase $(18 \%)$, and pyroxene $(14.5 \%)$. Because of its high glass content and very fine grain size, the mode of the matrix is approximate. Many of the plagioclase phenocrysts are 1 to $3 \mathrm{~mm}$, but others grade serially to groundmass size $(0.1 \mathrm{~mm})$. The phenocryst cores are sodic labradorite (approximately $\mathrm{An}_{52}$ ) with progressively (and in places oscillatory) zoned rims of calcic andesite. The plagioclase phenocrysts are commonly embayed and mottled by glass and contain glass and crystal inclusions similar to the glassy rock matrix. These inclusions probably resulted from partial resorption and subsequent partial crystallization. Minute, colorless glass inclusions with small spherical gas bubbles in some phenocrysts are probably the low pressure product of magma entrapped in the crystals during growth at higher pressure. Hypersthene and augite phenocrysts are typically 0.3 to $0.6 \mathrm{~mm}$ long, but larger crystals range to $2.5 \mathrm{~mm}$; a few hypersthenes show augite overgrowths. The nonvesicular glassy matrix contains plagioclase and pyroxene crystals 0.1 to $0.01 \mathrm{~mm}$ in length. The proportion of hypersthene to augite is much lower in the matrix (approximately 0.2) than in the phenocryst suite (approximately 0.8 ). The glass is very light brown in color and shows no apparent alteration.

Most other clasts are porphyritic, with plagioclase, augite, and hypersthene phenocrysts, but the proportion 
TABLE 4

Spectroscopic Trace Element Analyses of Leg 30 Igneous Rocks (in ppm)

\begin{tabular}{|c|c|c|c|c|c|c|c|}
\hline & $\begin{array}{c}(1) \\
285 \mathrm{~A}-7-6147 \mathrm{~cm} \\
\text { Diabase Chill Zone }\end{array}$ & $\begin{array}{c}(4) \\
286-36-1,132 \mathrm{~cm} \\
\text { Type } 1 \text { Basalt }\end{array}$ & $\begin{array}{c}\text { (5) } \\
286-37-1,72 \mathrm{~cm} \\
\text { Gabbro Chill } \\
\text { Zone }\end{array}$ & $\begin{array}{c}\text { (7) } \\
287-17, \mathrm{CC} \\
\text { Porphyritic } \\
\text { Basalt }\end{array}$ & $\begin{array}{c}(8) \\
287-18-1,147 \mathrm{~cm} \\
\text { Lower Basalt }\end{array}$ & $\begin{array}{c}\text { (9) } \\
289-132-3,50 \mathrm{~cm} \\
\text { Basalt }\end{array}$ & $\begin{array}{c}(10) \\
289-132-4,27 \mathrm{~cm} \\
\text { Basalt }\end{array}$ \\
\hline B & - & - & 10 & 7 & - & - & - \\
\hline $\mathrm{Ba}$ & 20 & 10 & 20 & 2 & 7 & 10 & 15 \\
\hline Co & 50 & 50 & 30 & 50 & 50 & 50 & 50 \\
\hline $\mathrm{Cr}$ & 70 & 500 & 500 & 700 & 500 & 300 & 300 \\
\hline $\mathrm{Ni}$ & 30 & 200 & 200 & 500 & 300 & 150 & 200 \\
\hline $\mathrm{Sc}$ & 70 & 50 & 50 & 70 & 70 & 70 & 70 \\
\hline $\mathrm{Sr}$ & 150 & 200 & 70 & 70 & 100 & 150 & 150 \\
\hline V & 200 & 150 & 150 & 150 & 200 & 200 & 200 \\
\hline $\mathrm{Y}$ & 50 & 20 & 20 & 15 & 20 & 30 & 30 \\
\hline $\mathrm{Zr}$ & 100 & 70 & 70 & 15 & 50 & 70 & 70 \\
\hline $\mathrm{Yb}$ & 5 & 3 & 3 & 1.5 & 2 & 3 & 5 \\
\hline
\end{tabular}

Note: The column number of each analysis corresponds to that of the major element analysis for the same sample given in Table 3 .

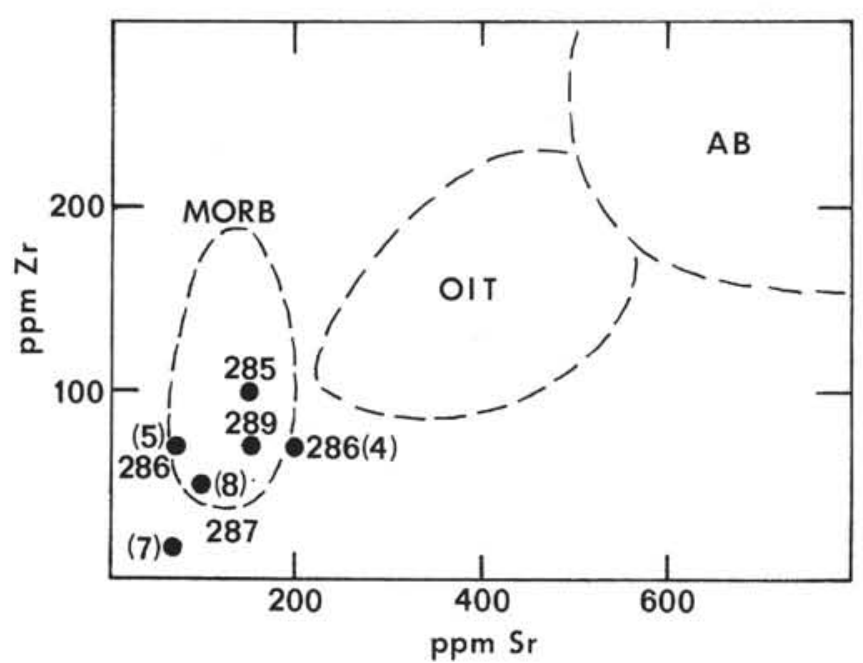

Figure 7. $\mathrm{Sr}$ versus $\mathrm{Zr}$ diagram for Leg 30 igneous rocks. Data used are taken from Table 4, and the numbers in parentheses are analysis numbers from that table. Field boundries are taken from Bass et al., 1973 (MORB= mid-ocean ridge basalts, OIT=ocean island tholeiites, $A B=$ alkali basalts).

of these phenocrysts varies. The cores of the plagioclase phenocrysts are largely sodic labradorite with rims that display oscillatory zoning and become progressively more sodic. The plagioclase phenocrysts commonly contain glass, glass-crystal, and glass/gas inclusions. Some hypersthene phenocrysts show well-developed augite reaction rims. The hypersthene/augite ratio varies, but in all rocks the matrix has a lower ratio than do the phenocrysts.

The matrix of the porphyritic clasts consists of hypersthene, augite, opaque minerals, plagioclase, and glass. The glass in many fragments shows no alteration except a slight change in color at clast margins that probably results from hydration. A few originally glassy clasts (tachylite) are altered to clay minerals; other glassy clasts that once contained finely disseminated opaque minerals have a reddish-brown color resulting from alteration of the opaques to hydrous iron oxides. Some finely crystalline clasts show reddish oxidation of the matrix minerals. A few clasts consist of tuff or basaltic sandstone in which the individual glassy fragments, plagioclase and pyroxene phenocrysts, are entirely altered.

Other clast types include broken or euhedral crystals of plagioclase, augite, and hypersthene, and rarely occurring green hornblende, epidote, and glauconite grains. One lithic clast consisting of plagioclase and uralitized pyroxene with intersitital quartz, and two clasts of hornblende andesite with elongate crystals of green hornblende, were also noted. Tests of diatoms and foraminifera and shell fragments form a minor proportion of the rock.

The groundmass of the conglomerate is composed of finely comminuted volcanic debris containing altered and fresh glass and crystals as well as clay and carbonate alteration products. Glass shards showing broken bubble wall junctions are rare, which is unusual considering the abundance of pumiceous fragments.

The pumiceous to moderately vesicular character of many of the clasts indicates their probable subaerial origin. The gross similarity of most volcanic clasts suggests that they were all derived from the same volcanic terrain. The coarse grain size of the cored rock and its poor sorting are consistent with transportation of the clasts to the depositional site by mass flow. The tests of foraminifera and diatoms, broken shell fragments, and other rare nonvolcanic grains (such as glauconite) probably were derived from bottom sediment that was incorporated into the moving mass. Some pumiceous lapilli tuffs have been interpreted as the result of shallow submarine eruption and redeposition by density currents (Fiske and Matsuda, 1964). Although the clasts may have been derived from submarine eruption, they show sufficient diversity to suggest that material from more than one eruption is represented. The general lack of oxidation shown by the 
clasts would not be expected if they originated in submarine eruptions.

\section{Basalt $(0-10 \mathrm{~m})$}

Basalt was first encountered in Core 36, Section 1, but the top $27 \mathrm{~cm}$ of this core liner was empty and the contact with the overlying middle Eocene sediment was lost. The sediment at the base of the overlying core is soft and discolored and contains abundant iron oxide and glass shards which have been altered to clay or zeolite. Although 10 meters of basalt were cored, only 2 meters were recovered.

Two intercalated types of basalt are recognized within the unit: (1) a dense, dull black, very fine-grained basalt which has a quench texture, and (2) a brown-stained basalt, much of which has a well-developed variolitic texture, and which contains sparse, small calcium carbonate amygdules. These two types alternate throughout the unit as follows:

\begin{tabular}{cccc}
\hline Type & Core & Section & Interval $(\mathrm{cm})$ \\
\hline 1 & 36 & 1 & $26-31$ \\
2 & 36 & 1 & $31-50$ \\
1 & 36 & 1 & $50-53$ \\
2 & 36 & 1 & $53-125$ \\
1 & 36 & 1 & $125-142$ \\
2 & 36 & 1 & $142-150$ \\
1 & 36 & CC & $0-2$ \\
2 & 36 & CC & $2-33$ \\
empty & 37 & 1 & $0-20$ \\
2 & 37 & 1 & $20-68$ \\
\hline
\end{tabular}

In addition to these two main types of basalt, several thin seams (up to a centimeter thick) of clear brown sideromelane which was sometimes accompanied by dolomite, cut the basalt.

The type 1 basalt has a quench texture consisting of an interlocking mosaic of feathery pyroxene less than $100 \mu \mathrm{m}$ in diameter, occult plagioclase, and approximately five to ten percent olivine (Figure $8 \mathrm{~B}$ ). The olivine occurs as small phenocrysts (up to $0.7 \mathrm{~mm}$ in diameter) that include small euhedral chromites and as quench crystallites, some of which have the lantern form. Much of this rock, including serpentinization of most of the olivine, appears to be extensively altered, but fresh olivine was encountered in thin section 36-1, $132 \mathrm{~cm}$.

The brown type 2 basalt is texturally somewhat more complex. The most distinct megascopic feature is the occurrence of large variolitic structures (up to $2 \mathrm{~cm}$ in diameter), which have coalesced into bands in some places. A strong impression that the varioles have grown at the expense of the type 1 basalt is gotten from observation of some core pieces. The varioles consist of radiating acicular hollow plagioclase, pyroxene(?), fine magnetite, chlorite, and calcium carbonate (similar to the texture shown in Figure 8C). As in the type 1 basalt, euhedral olivine phenocrysts, up to approximately $1 \mathrm{~mm}$ in diameter, are present but are usually altered. Essentially all the brown type 2 basalt shows some degree of hydrous alteration (indicated by chlorite, calcite, iron staining, and the replacement of the olivine phenocrysts by serpentine or iron-oxide, and calcite).
Sideromelane occurs as clasts in a dolomite vein (36-1, $43 \mathrm{~cm})$ and as two thin seams $(36-1,125 \mathrm{~cm}$ and $37-1,70$ $\mathrm{cm})$. Where fresh, the sideromelane is a deep reddish amber color and contains phenocrysts of olivine with small euhedral inclusions of chromite (Figure 8A). The occurrence of fresh sideromelane seams in the altered basalt strongly suggests that these glasses are younger than the basalt and were ejected along fractures. The seam at $37-1,70 \mathrm{~cm}$, which tentatively marks the basaltgabbro boundary, appears hydrated and has good flow structures that indicate that it was injected from below from the direction of the gabbro (Figure 8D).

In addition to the carbonate associated with the sideromelane seams, veins of carbonate up to $1 \mathrm{~cm}$ thick are common throughout the basalt unit. It seems probable that the carbonates associated with the sideromelane were deposited in fractures that opened along the weak glass seams, and in at least one case fragmented them so that clasts of sideromelane were incorporated in the dolomite. Possibly these veins formed during the period when the gabbro and/or basalt were being altered.

The only mineral analyses available are of the fresh olivine phenocrysts (and their included chromites) from sideromelane Sample 36-1, $125 \mathrm{~cm}$ (Figure 5A) and type 1 basalt Sample 36-1, $132 \mathrm{~cm}$ (Figure 8B). The olivine phenocrysts of both samples were almost identical in composition (Fos6-88). The spinels were virtually the same, and a typical analysis (in weight percent) is $\mathrm{MgO}$, 11.8; $\mathrm{FeO}, 23.4 ; \mathrm{Cr}_{2} \mathrm{O}_{3}, 39.2 ; \mathrm{Al}_{2} \mathrm{O}_{3} ; 23.1$; and $\mathrm{TiO}_{2}, 1.3$, yielding the atomic ratios $\mathrm{Fe} /(\mathrm{Fe}+\mathrm{Mg})=0.53$ and $\mathrm{Cr} /(\mathrm{Cr}+\mathrm{Al})=0.53$.

The type 1 basalt and sideromelane are compositionally similar, both being olivine normative high alumina basalts (Table 3, Figure 5). Their titanium and phosphorous contents are similar to mid-ocean ridge basalts (Figure 6), as are the trace elements of the type 1 basalt sample (Table 4, Figure 7). The high potash content of the type 1 basalt sample suggests that at least some alteration has occurred; this was also indicated from thin-section observations.

\section{Gabbro (10-57 m)}

The contact between the basalt unit and the gabbro is tentatively drawn between two pieces of core at 37-1, 70 $\mathrm{cm}$. The contact is marked by a sideromelane seam and a change in color from the overlying brown basalt to a gray diabase below. In the $6-\mathrm{cm}$ core piece immediately below the contact, the following changes were observed going downward:

1) a hydrated sideromelane glass, $1.5 \mathrm{~mm}$ thick; with flow structure and sparse serpentine-calcite pseudomorphs after olivine phenocrysts (Figure 8D);

2) a $0.25-\mathrm{mm}$-thick zone of calcium carbonate spherules (Figure $8 \mathrm{D}$ );

3) a fine-grained chloritized or montmorillonitized zone, $1-\mathrm{cm}$ thick, which consists of a mosaic of altered feathery microlites; and

4) a variolitic zone, approximately 4-cm thick (Figure $8 \mathrm{C})$

In the meter and a half below this core piece the texture of the rock gradationally changes from variolitic to diabasic, and the grain size rapidly increases to ap- 

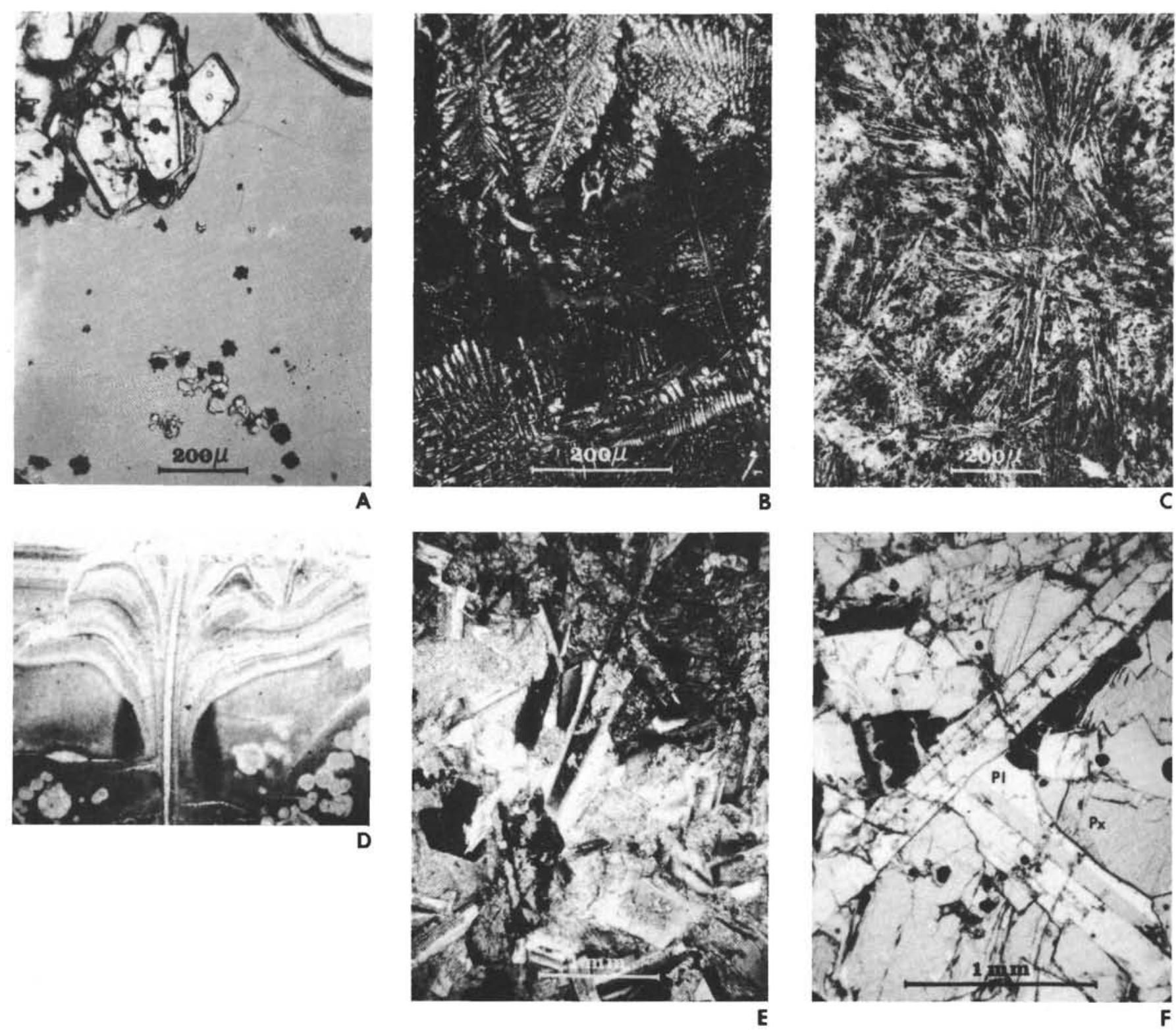

Figure 8. Photomicrographs of Site 286 samples. (A) 286-36-1, $125 \mathrm{~cm}$, fresh sideromelane from a vein in the Unit 4 basalt, which contains euhedral olivine phenocrysts. The large olivines contain chromite inclusions. The black star-shaped clusters are incipient crystallization of the glass and have approximately the same composition as the glass. Each of them has a small chromite nucleus. (B) 286-36-1, $132 \mathrm{~cm}$, fresh quench-textured Unit 4 basalt with feathery pyroxene and lantern olivine (top center) (crossed polarizers). (C) 286-37-1, $77 \mathrm{~cm}$, Unit 5 variolithic chill zone basalt, in which the plagioclase has been replaced by potassium feldspar (uncrossed polarizers). (D) 286-37-1, $70 \mathrm{~cm}$, hydrated sideromelane which contains flow structures indicating that it was extruded from below from the direction of the gabbro, and which marks the contact between the Unit 4 basalt and the Unit 5 gabbro (uncrossed polarizers, long dimension of the photograph equals approximately $1 \mathrm{~cm}$ ). (E) 286-38-4, $100 \mathrm{~cm}$, extensively altered gabbro in which much of the plagioclase and pyroxene have been replaced by fine-grained smectite and chlorite (crossed polarizers). Note the large subhedral quartz crystal (black) near the center of the left margin. (F) 286-39-4, $40 \mathrm{~cm}$, fresh Unit 5 gabbro (pl-plagioclase, px-pyroxene, partially crossed polarizers).

proximately $1.5 \mathrm{~mm}$. This 1.5 -meter interval appears to constitute a chill zone at the top of the gabbro.

The gabbro is medium grained throughout, with average grain sizes in the range 1.5 to $3.5 \mathrm{~mm}$, coarsening gradationally downward (Figure 5F). The gabbro is generally altered, but originally consisted of ap- proximately $50 \%-60 \%$ plagioclase, $35 \%-40 \%$ pyroxene, and 5\% magnetite (titanomagnetite?). The magnetite is often euhedral, but may be skeletal. Less than $1 \%$ euhedral quartz, with a maximum diameter of $0.2 \mathrm{~mm}$, is present throughout the gabbro (Figure $8 \mathrm{E}$ ). The textural relationships of the quartz are such that it could be 
either late primary or a product of the hydrous alteration process.

Two notable changes occur within the gabbro. In Section 286-38-4 the amount of alteration shows a sudden increase from an overall average of approximately $25 \%$ to over 50\%; over the next few meters, alteration decreases gradationally downward, back to average. Second. Section 286-41-1 shows a sharp decrease in average grain size, from approximately $3.5 \mathrm{~mm}$ in the core immediately above to approximately $1.5 \mathrm{~mm}$ (Figure 2). Below Section 286-41-1, the average grain size increases gradationally downward, and within 9 meters (at the bottom of the hole) has reached approximately $3 \mathrm{~mm}$. This sudden decrease in grain size probably indicates that at least two intrusive phases of the gabbro are present.

The plagioclase of the gabbro shows a marked normal zoning. The cores have compositions in the range $\mathrm{An}_{74-}$ 67, and the full range of compositions is $\mathrm{An}_{74-25}$ (Figure 9). The plagioclase has a low potash content; maximum orthoclase content was Oro.s for the $\mathrm{An}_{25}$ analysis and $\mathrm{Or}<0.25$ for all others. Because of the extensive alteration, pyroxene compositions were only determined for two samples. These pyroxenes are augites that exhibit little compositional zoning; most analyses fall on the trend $\mathrm{En}_{48-40} \mathrm{~W}_{\mathrm{O}_{43-40}} \mathrm{Fs}_{10-20}$ (Figure 4B).

Chemical analyses of the gabbro chill zone rock show that it has been extensively altered. Most notably there appears to be an extensive depletion of $\mathrm{CaO}$ and $\mathrm{Na}_{2} \mathrm{O}$ and a marked increase in $\mathrm{K}_{2} \mathrm{O}$ (Table 3, analysis 5). A microprobe analysis of the felsic portion of the groundmass indicates that it consists almost entirely of potassium feldspar (Table 3, analysis 6). This replacement of the plagioclase by potassium feldspar did not strongly affect the primary variolitic texture of this rock (see Figure $8 \mathrm{C}$ ). The alteration of the chill zone rock was sufficiently severe to make it impossible to delineate the original chemistry clearly, although it was obviously basaltic.

\section{Discussion}

The relationship between the basalt and the gabbro is not clear. The basic question is whether the chosen contact between them is indeed a contact at all. If it is not,

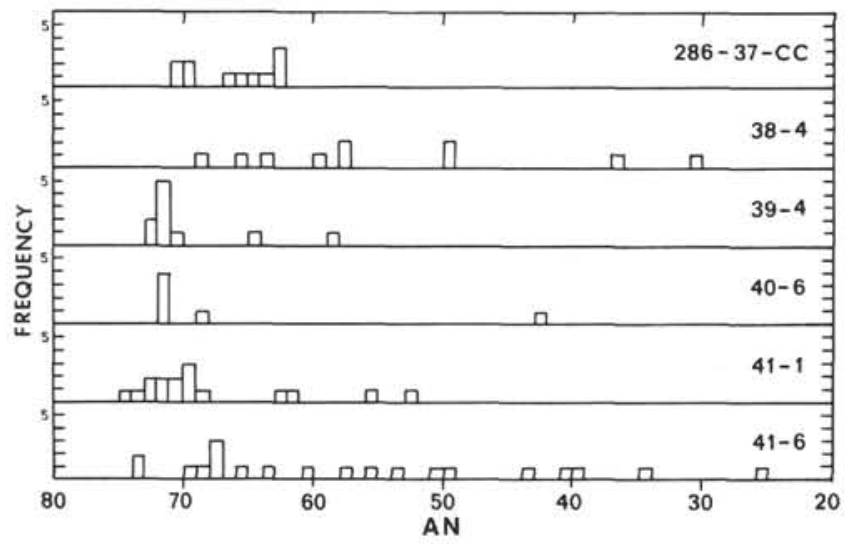

Figure 9. Plagioclase histograms for Site 286 gabbro samples. The maximum orthoclase content for any sample was 0.5 and most contained less than 0.25 . then the basalt and gabbro are probably all one unit, since no other location for a contact is obvious. In this case, the gabbro has an 11.5-meter-thick chill zone of which over 10 meters is quench-textured basalt. Although this seems unlikely, the evidence for a contact is weak, it being based mainly on a sudden color change, which may be related to degree of alteration.

Indeed, the variolitic basalts on either side of the contact look very much alike. Unfortunately, because of the intense alteration of the gabbro chill zone, a chemical comparison cannot be made between the basalt and the gabbro chill zone with the data available.

Even if the contact between the basalt and gabbro is real, questions remain. If the basalt overlying the gabbro is simply an older unrelated flow, then we must accept the odd situation in which a gabbroic intrusion penetrated completely through the basement except for this topmost flow, or the possibility that the basalt somehow represents an early phase of the gabbro intrusion. Secondly, the relationship of the sideromelane to the basalt and gabbro is unclear. Even if the sideromelane was intruded into the basalt from below, as its occurrence at the basalt-gabbro "contact" suggests, it is difficult to understand how fresh sideromelane glass survived whereas both the gabbro and basalt have undergone extensive hydrous alteration. Thirdly, we have the strange relationship between the two types of basalt in the basalt unit. If it is correct that the type 2 basalt replaces the type 1 basalt, then perhaps the type 2 basalt is a devitrification or recrystallization of the type 1 basalt which was induced by the elevated temperatures resulting from the intrusion of the gabbro. Finally, if the basalt is a flow, then the alteration of the sediment immediately above the basalt must be explained as a result of halmyrolysis or the emplacement of the gabbroic intrusion only some 10 meters below.

Because of the lack of extensive alteration to the overlying sediments and their textures, and thickness of the basalt, which seems too great to be accounted for as a chill zone of the gabbro intrusive, a flow origin for the basalt unit is preferred. Unfortunately, the ultimate interpretation of this important site and its regional significance is tied to the interpretation of origin of these rocks and the question of whether or not true basement was reached. Therefore, a more thorough investigation of the Site 286 igneous rocks and overlying sediments is merited.

\section{SITE 287}

Basalt was first encountered at 240 meters below the mudline. The two basalt flows sampled (Figure 2) consist of an upper porphyritic flow and a lower flow which is distinct from the overlying basalt in the near absence of phenocrysts and in being considerably more altered. The apparent total thickness of the porphyritic basalt is 5.7 meters of which 4.4 meters of core were recovered. Only 1 meter of the lower basalt was recovered although 10 meters were cored.

\section{Porphyritic Basalt (0.0-5.7 m)}

The actual contact between the basalt and overlying lower Eocene sediment is not preserved, and the transition occurs in the form of a core piece of sediment sitting 
upon one of basalt. The nannochalk a few centimeters above the basalt is not baked, and nannoplankton tests are well preserved. The sediment immediately above the basalt is olive-gray as compared to the bluish-gray of the sediment in the overlying two cores; the color change is ascribed to weathering of the adjacent basalt.

This basalt is characterized by abundant large phenocrysts and glomerocrysts of plagioclase and olivine set in a fine-grained groundmass (Figure 10A, B). The top and base of the porphyritic basalt are very fine grained and exhibit quench textures which grade from subvariolitic to intergranular and subophitic in the middle and lower parts of the unit. Because of the apparent lack of baking of the overlying sediments and the basaltic textures throughout the unit, it is concluded that the porphyritic basalt is a flow. A modal analysis of thin section $287-17, \mathrm{CC}$ yielded ( 250 points):

$\begin{array}{lr}\text { olivine phenocrysts } & 5.5 \% \\ \text { groundmass pyroxene and olivine } & 48.0 \% \\ \quad \text { (approx. 3\%-5\% olivine) } & \\ \text { plagioclase phenocrysts } & 14.5 \% \\ \text { groundmass plagioclase } & 25.6 \% \\ \text { opaque minerals (largely magnetite) } & 4.0 \% \\ \text { chloritic alteration } & 4.0 \% \\ \text { chloritic amygdules } & 0.4 \%\end{array}$

Moderate chloritic or montmorillitic alteration of the groundmass is present throughout most of the unit, although much of the rock in Sample 17, CC is very fresh. Calcite and/or chlorite veins up to $1.5 \mathrm{~cm}$ thick and only a few centimeters apart are present throughout the unit. Small chlorite amygdules, less than $2 \mathrm{~mm}$ in diameter, are present in all samples examined.

Fresh phenocrystal and groundmass olivine with some serpentine along fractures was found in 287-17, CC. Because this was the only fresh rock examined in thin section, all mineral compositional data reported for the porphyritic basalt were obtained from this sample. In all other samples examined only serpentine-calcite psuedomorphs after olivine were observed. The olivine phenocrysts are less than $2.5 \mathrm{~mm}$ in diameter, unzoned, and have a very uniform composition of Fos9. The phenocrystal plagioclase occurs both as single crystals up to $5 \mathrm{~mm}$ in length, and as glomerocrysts sometimes accompanied by olivine (Figure 10B). Most of the phenocrystal plagioclase exhibits moderate normal zoning with occasional oscillatory zoning. Margins of the plagioclase show signs of resorption. Strongly rounded cores in some phenocrysts which have euhedral or subhedral exteriors indicate a cyclic history of resorption and regrowth. The inner one-third of the plagioclase phenocrysts are typically clouded with irregular subspherical brown inclusions, which are probably fluid, inasmuch as they are found to be pits on polished surfaces. The anorthite contents of the phenocrystal plagioclase are in the range $\mathrm{An}_{89-69}$, with most values being greater than $\mathrm{An}_{84}(14$ determinations), and the content of orthoclase component is less than 0.12 for all analyses. The groundmass plagioclase has a compositional range of $A_{83-67}$ (6 determinations) and Or less than 0.12.

A small number of three-element microprobe analyses $(\mathrm{Mg} / \mathrm{Ca} / \mathrm{Fe})$ of the groundmass pyroxene indicates that the pyroxene is augite. The pyroxene is zoned such that the enstatite content is approximately constant, but the wollastonite and ferrosilite show a covariance, with the most calcic augite being early (Figure 4C). The survey of the pyroxenes was not adequate to detect moderate amounts of a low calcium pyroxene if present.

The porphyritic basalt is an aluminous tholeite with a very low alkali content (Table 3, Figure 5). It has the highest content of $\mathrm{Cr}, \mathrm{Cu}$, and $\mathrm{Ni}$ of any of the samples analyzed (Table 4) and has lower concentrations of $P$, $\mathrm{Ti}, \mathrm{Ba}, \mathrm{Sr}$, and $\mathrm{Zr}$ than even the mid-ocean ridge basalts, possibly indicating a very depleted source region (Figures 6,7). The rather peculiar chemical composition of this rock combined with the textural evidence which indicates a complex crystallization history clearly makes this an unusual and interesting oceanic basalt. In turn it was taken from the floor of the Coral Sea Basin, a marginal basin, whose origin is at best poorly understood.

\section{Lower Basalt (5.7-15.7 m)}

The contact between this basalt and the overlying porphyritic basalt was not preserved, but the marked decrease in grain size at the base of the porphyritic basalt and the quench texture of the top piece of core from this unit suggests that little of the contact zone was lost. This basalt contains sparse phenocrysts of plagioclase $\left(\mathrm{An}_{78-74}, \mathrm{Or}<0.10\right)$ and altered olivine. No fresh olivine was found in thin section, and the original presence of olivine phenocrysts is indicated by serpentine pseudomorphs. The average grain size of the groundmass increases downwards from the top, accompanied by a change from a quench texture to an intersertal texture (Figure 10C). The groundmass is extensively montmorillitized or chloritized throughout and no primary mafic silicates remain. Chlorite(?) amygdules less than $1.5 \mathrm{~mm}$ in diameter are ubiquitous but constitute less than $1 \%$ of the rock. In spite of the alteration, the major element chemistry appears "reasonable" and is that of a high alumina basalt, with $18.7 \% \mathrm{Al}_{2} \mathrm{O}_{3}$ (Table 3 , Figure 5). Its minor and trace element chemistry is similar to that of mid-ocean ridge basalts although on the depleted side, and to some degree it resembles that of the porphyritic flow (Table 4, Figures 6,7).

\section{SITE 289}

Fresh to moderately altered basalt was encountered at 1262 meters below the mudline and 9.2 meters of basalt were cored, of which 4.1 meters were recovered. The core is subdivided into two portions, an upper 3.7 meters and a lower 0.4 meters, which are separated by an empty zone of 3.5 meters (Figure 2). The lower basalt appears to be identical with the upper. The basalt is overlain by a sequence of intercalated limestones and vitric tuffs of Early Cretaceous age. The contact with the overlying sediments was not preserved, but the sediment immediately above the top core piece of basalt is a grayish-brown tuff which contains well-preserved nannofossils.

The basalt has a chill zone approximately $10 \mathrm{~cm}$ thick. The chill zone rock changes downwards from a welldeveloped variolitic texture at the top (Figure 10D) to an intergranular texture at the bottom. Only a small amount of groundmass plagioclase was able to 

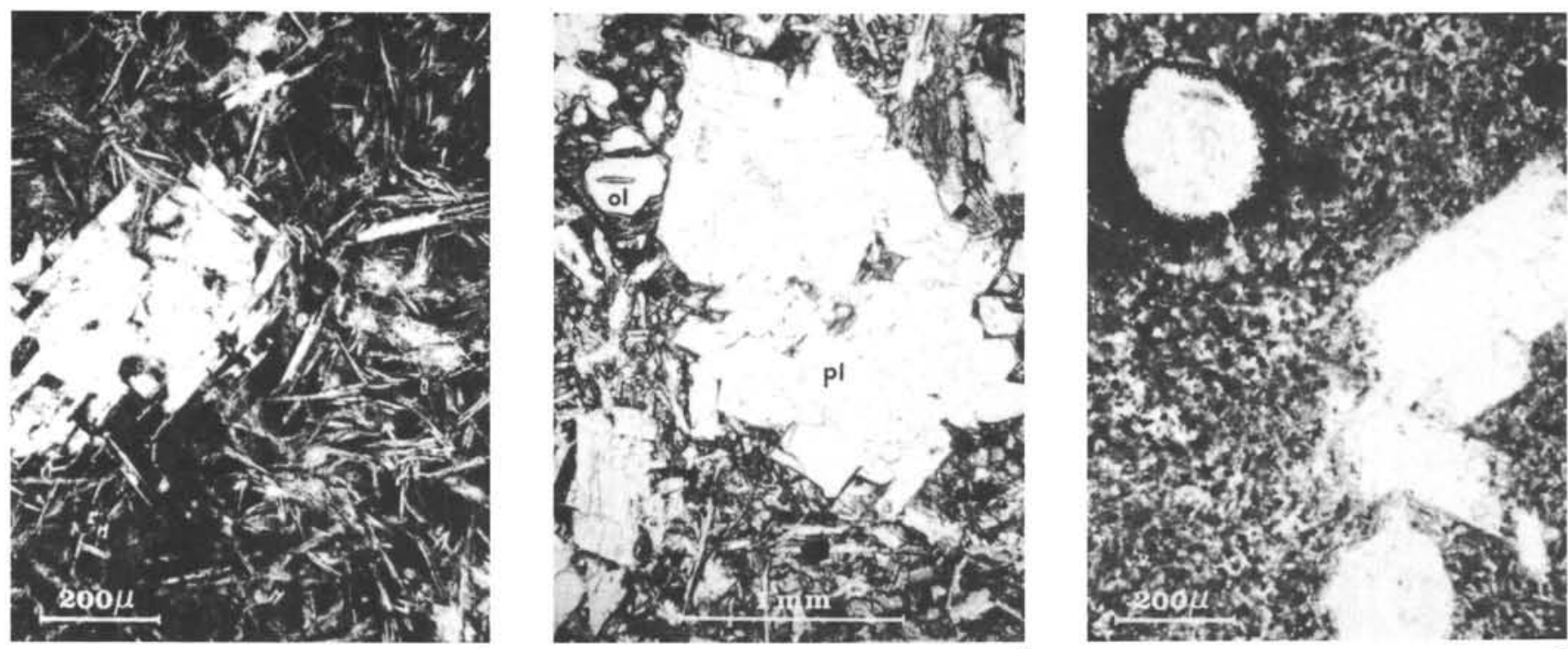

A

B

C
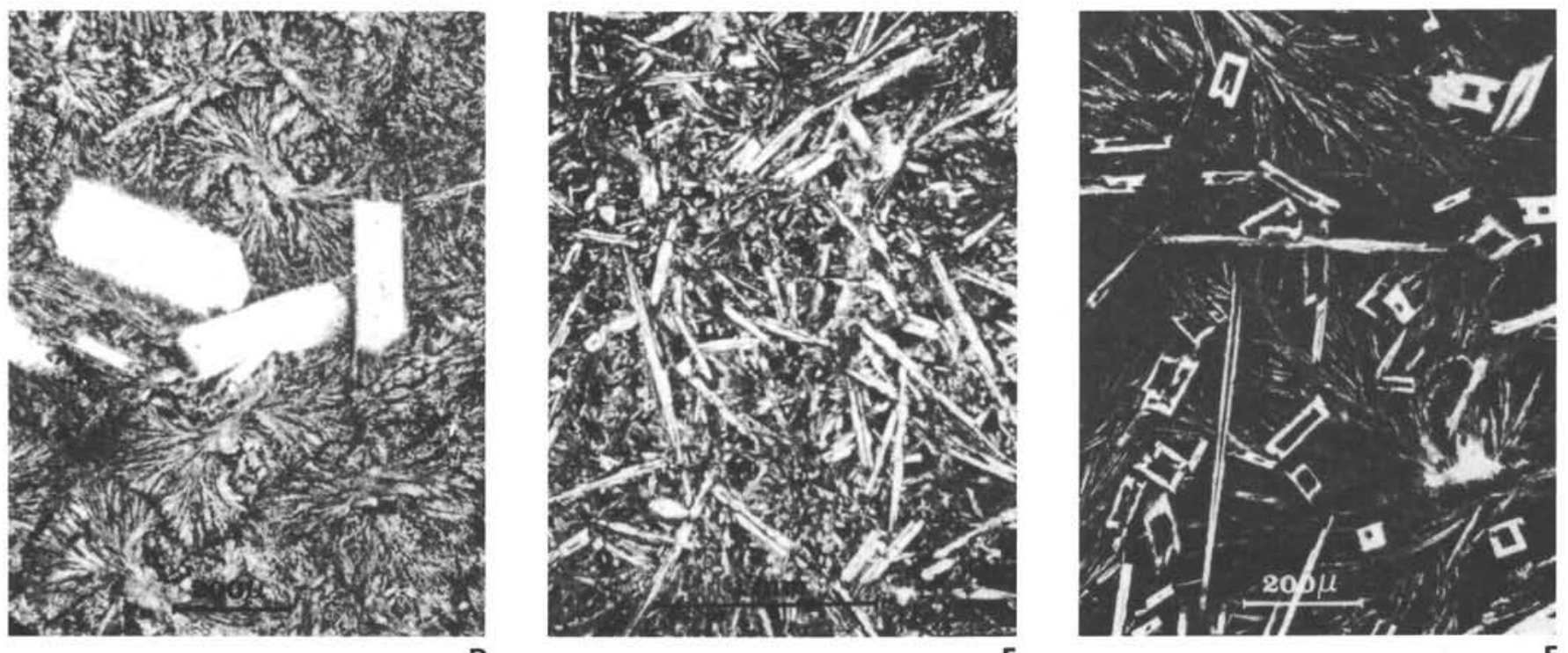

$\mathbf{E}$

Figure 10. Photomicrographs of Site 287 and 289 basalts. (A) 287-16-1, $83 \mathrm{~cm}$, chilled margin of the Unit 6 porphyritic basalt (uncrossed polarizers). Note the large irregular partially resorbed plagioclase phenocryst. (B) 287-17, CC, fresh Unit 6 porphyritic basalt with glomerocryst of plagioclase (pl), and olivine (ol) which has been partially replaced by serpentine (uncrossed polarizers). (C) 287-18-1, $148 \mathrm{~cm}$, highly altered Unit 7 basalt in which the groundmass has been extensively "chloritized"'(uncrossed polarizers). The phenocrysts are plagioclase, and the amygdule is filled with chlorite. (D) 289-1323, $148 \mathrm{~cm}$, "coarse" intergranular basalt (uncrossed polarizers). (F) 289-133-1, $140 \mathrm{~cm}$, variolithic basalt with welldeveloped hollow (intrafasciculate) plagioclase and feathery quench pyroxene in a dense finely crystalline groundmass (uncrossed polarizers).

crystallize before the lava of the top few centimeters was quenched. The chill zone rock contains small altered phenocrysts of $2 \%$ plagioclase and less than $1 \%$ olivine. The groundmass consists of hollow plagioclase, variolitic to subvariolitic pyroxene, dendritic quench magnetite, and chloritized glass (?).

The basalt from Site 289 consists of alternating zones of coarser grained intergranular basalt and finer grained variolitic quench basalt. The intergranular zones have an average grain size of less than $0.3 \mathrm{~mm}$ and contain acicular plagioclase (largely without the hollow habit), and pyroxene which generally occurs in subvariolitic sheaf-like bundles (Figure 10E). The finer grained variolitic basalt has very well-developed hollow acicular plagioclase, fine variolitic pyroxene, small dispersed euhedral magnetite, and very fine-grained interstitial 
material (Figure 10F). Indistinct to distinct thin horizontal flow laminae are present in many parts of the basalt, but appear to be better developed in the intergranular zones. Vesicles less than $2 \mathrm{~mm}$ in diameter are present sporadically throughout the unit, but never exceed about $1 \%$ of the rock. A table of the various zones is presented below:

\begin{tabular}{lccc}
\hline \multicolumn{1}{c}{ Lithology } & Core & Section & Interval $(\mathrm{cm})$ \\
\hline Chill zone & 132 & 2 & $82-92$ \\
Intergranular basalt & 132 & 2 & $92-150$ \\
Intergranular basalt & 132 & 3 & $0-48$ \\
Variolitic basalt & 132 & 3 & $48-78$ \\
Intergranular basalt & 132 & 3 & $78-150$ \\
Intergranular basalt & 13,2 & 4 & $0-12$ \\
Variolitic basalt & 132 & 4 & $12-65$ \\
Intergranular basalt & 132 & 4 & $65-150$ \\
Empty & 132 & 1 & $0-107$ \\
Intergranular basalt & 133 & 1 & $107-118$ \\
Variolitic basalt & 133 & 1 & $118-150$ \\
\hline
\end{tabular}

Groundmass plagioclase and pyroxene from two samples $(132-2,90 \mathrm{~cm}$, chill zone, and $132-3-50 \mathrm{~cm}$, variolitic basalt) were analyzed. The plagioclase compositions of the two samples are very similar, with anorthite contents in the range $A_{n_{74}-63}$ and orthoclase contents of $\mathrm{Or}<0.4$. The pyroxene is augitic, with all analyses falling within the narrow range of $\mathrm{En}_{46-40} \mathrm{~W} \mathrm{Wo}_{43}-$ ${ }_{40} \mathrm{Fs}_{11-20}$ (Figure $4 \mathrm{~d}$ ).

Small plagioclase phenocrysts, usually less than $1 \mathrm{~mm}$ in length, are present throughout the Site 289 basalt in amounts of less than $2 \%$. The plagioclase phenocrysts in most samples examined have been replaced by calcite and an unidentified clear, low birefringent, optically negative mineral with a $2 \mathrm{~V}$ of approximately $20^{\circ}$. Phenocrysts of olivine less than $1.5 \mathrm{~mm}$ in diameter, which have been altered to iddingsite and chlorite in amounts not exceeding $1 \%$, are unevenly distributed throughout the unit.

Veins up to $1.5 \mathrm{~cm}$ are abundant, particularly in the basalt of Core 132, Sections 2 and 3. The vein minerals consist of chlorite, calcite, rare pyrite, and a yellowishbrown siliceous(?) material. Two irregular cavities associated with the calcite-chlorite veins were lined with small quartz and calcite crystals.

In conclusion, the basalt represents a flow, as evidenced by the lack of baking of the overlying sediment and tuff, the basaltic textures, and the flow structures which occur throughout the unit. The intercalation of the variolitic and intergranular basalt types might be interpreted as a sequence of thin flows, rather than a single flow; but in some cases the transition from one type to another occurs gradationally within single solid core pieces.

The two major element analyses which are available show that the basalt from Site 289 is compositionally similar to the mid-ocean ridge tholeiites (Table 3, Figure 5). It appears to be just saturated, as one analysis is slightly olivine normative and the other slightly quartz normative, although this may well be an artifact of the $\mathrm{Fe}^{+3} / \mathrm{Fe}^{+2}$ ratio of 0.2 used for the norm calculations. The minor and trace element concentrations are also similar to those of the mid-ocean ridge tholeiites (Table 4, Figures 6,7). Although samples from one flow are hardly definitive, there is no evidence to indicate that the basement of the enormous Ontong-Java Plateau is other than typical oceanic tholeiite.

\section{ACKNOWLEDGMENTS}

In particular I would like to thank David L. Jones of the U.S. Geological Survey and Brian K. Holdsworth of the University of Keele for their stimulating onboard conversations and helpful advise in regards to the hard rock petrography, and to Dave for his ready helping hand. I also wish to thank the U.S. Geological Survey and David Jones who gave invaluable aid in providing the chemical analyses. And finally, I would like to express my appreciation to John A. Wood of the Smithsonian Astrophysical Observatory for use of his laboratory and other aid, and to Ms. Karen Motylewski of the Observatory for her help in editing and preparing the manuscript.

\section{REFERENCES}

Bass, M.N., Moberly, R., Rhodes, J.M., Shih, C., and Church, S.E., 1973. Volcanic rocks cored in the Central Pacific, Leg 17, Deep Sea Drilling Project. In Winterer, E.L., Ewing, J.I., et al., Initial Reports of the Deep Sea Drilling Project, Volume 17: Washington (U.S. Government Printing Office), p. 429-503.

Deer, W.A., Howie, R.A., and Zussman, J., 1962. Rockforming minerals: v. 1, ortho and ring silicates: London (William Clowes \& Sons, Ltd.).

Fiske, R.S., and Matsuda, T., 1964, Submarine equivalents of ash flows in the Tokiwa Formation, Japan: Am. J. Sci., v. 262 , p. $76-106$.

Kuno, H., 1968. Differentiation of basaltic magmas. In Hess, H.H. and Poldervaart, A., (Eds.), p. 623-688.

MacDonald, G.A. and Katsura, T., 1964. Chemical composition of Hawaiian lavas: J. Petrol., v. 5, p. 82-133.

Rhodes, J.M., 1973. Major and trace element chemistry of basalts from Leg 9 of the Deep Sea Drilling Project: EOS, v. 54 , p. $1014-1015$. 